\title{
Medisinsk fødselsregister fyller femti- Kan olje lære oss noe om helsedata?
}

\author{
Camilla Stoltenberg \\ Direktør, Folkehelseinstituttet \\ camilla.stoltenberg@fhi.no
}

This is an open access article distributed under the Creative Commons Attribution Licence, which permits unrestricted use, distribution, and reproduction in any medium, provided the original work is properly cited.

Medisinsk fødselsregister fyller femti. Det er en anledning til å feire kunnskapen registeret har gitt oss, metodene som er utviklet med fødselsregisterdata som kilde og testarena, og ikke minst alle som har utviklet registeret med engasjement, kompetanse, kreativitet og utholdenhet. Samtidig er det en anledning til å løfte blikket, se fødselsregisteret i en større sammenheng som del av en familie av registre, helseundersøkelser, biobanker og andre helsedata, og tenke på hvilke nye utfordringer som er de viktigste.

Fødselsregisteret er del av en lang historie med flere stammødre og stamfedre. Det går linjer tilbake til Lepraregisteret og Eilert Sundts innsamling av opplysninger om giftemål og fødsler i Norge på 1800tallet. Da fødselsregisteret ble født i 1967 var det siste tilskudd i en liten, eksklusiv familie der Dødsårsaksregisteret og Kreftregisteret var de eneste å regne med. Folkeregisteret kan kanskje regnes som en felles stammor eller stamfar, registeret som sammen med personnummeret gir andre registre og forskning om folk i Norge spesielt gode vilkår. Folkeregisteret er avgjørende både for skattesystemet, driften av samfunnet fra dag til dag, og for fremgangsrike deler av forskningen i Norge. I Statistisk sentralbyrå finnes registre med opplysninger om fødeland, utdanning, inntekt, yrke og folketrygd - alt dette er viktig for helsetilstanden, helsetjenestene og folkehelsearbeidet, men juridisk og institusjonelt er disse datakildene ikke med i helseregisterfamilien. De utgjør en annen gren.

En stund var Kreftregisteret og fødselsregisteret nokså alene som helseregistre, og analysene begrenset seg hovedsakelig til det hvert enkelt register ga av muligheter. Først sent på 1970-tallet fikk vi smittevernregistre med Meldingssystem for smittsomme sykdommer (MSIS) og Tuberkuloseregisteret, og i 1998 ble vaksinasjonsregisteret - System for vaksinasjonskontroll (SYSVAK) - etablert. Slik ble beredskap, løpende overvåking, etterforskning og håndtering av utbrudd av smittsomme sykdommer et tydelig formål.

Fra 2002 har utviklingen gått raskere, i hvert fall hvis vi teller antall registre. Reseptregisteret ble etablert i 2004. Samme år fikk de regionale helseforetakene i oppdrag å utvikle nasjonale medisinske kvalitetsregistre og siden den gang er det etablert mer enn 50 slike registre. I 2007 vedtok Stortinget etablering av Norsk pasientregister som et personidentifiserbart register med diagnoser og prosedyrer fra spesialisthelsetjenesten, i 2010 ble hjertekarregisteret vedtatt, i 2011 ble registeret for genetisk masseundersøkelse av nyfødte vedtatt, og i 2016 vedtok Stortinget etablering av et Kommunalt pasient- og brukerregister. Flere registre er under planlegging, blant annet et nasjonalt register for laboratoriedata og et for legemidler som skal omfatte både de som er utlevert på apotek slik de finnes i reseptregisteret $i$ dag, og opplysninger om legemiddelbruk i sykehus, sykehjem og andre institusjoner.

Helseregistrene skal bidra til bedre beredskap, overvåking og helseanalyse, høyere kvalitet $i$ helsetjenestene, økt pasientsikkerhet, flere kliniske utprøvinger, bedre folkehelsearbeid, effektiv bruk av ressursene og riktige prioriteringer, vitenskapelige oppdagelser, kunnskapsbasert innovasjon og utvikling av helsenæringer - for å nevne noen av formålene og forhåpningen. Stadig nye grupper oppdager verdien av helsedata og melder seg på i debatten. Forpliktelsene og forventningene er store og øker. «Helsedata er den nye oljen» og «Helsedata er arvesølvet», er overskrifter som går igjen, og selv om det finnes helsedata utenfor registrene, er helseregistrene sammen med de demografiske og sosioøkonomiske registrene det som gjør både registrene og andre helsedata i Norge spesielt attraktive. Mulighetene for å koble registre sammen utnyttes i stadig større grad, og etterspørselen etter slike datasett $ø$ ker kontinuerlig. Lovverket, forvaltningen og organiseringen av helsedata holder ikke tritt og det kan ta år før man får tilgang til datasett for å svare på hastespørsmål om hvordan mors bruk av antidepressiva påvirker fostre, eller om pandemivaksinen hadde andre alvorlige bivirkninger enn narkolepsi.

Direktoratet for e-helse har fra 2017 fått ansvar for å lede arbeidet med å følge opp helseregisterstrategien, og sørge for at den videre utviklingen av fellesløsninger for registrene er godt integrert $\mathrm{i}$ e-helsearbeidet. Det er lovende, men det forutsetter politisk vilje på høyeste nivå. Etter påtrykk fra HelseOmsorg21-rådet og andre utpekte Helsedepartementet i 2016 et ekspertutvalg for bedre tilgang til helsedata. Utvalget leverte sin rapport på forsommeren 2017 og nå er det viktig at denne følges opp.

Bedre tilgang til helsedata er avgjørende for å nå målene med registrene, men det utløser et akutt behov for å svare på minst ett grunnleggende spørsmål: Hvordan skal Norge sørge for en god demokratisk forvaltning av registre og andre helsedata? Hvordan skal vi sikre at helsedata kommer befolkningen til gode og fortsetter å gjøre det? Og mer spesifikt: Hvordan skal 
vi unngå at aktører med sterk økonomi og økonomiske interesser får mer enn rimelig innflytelse på utviklingen av registrene og andre helsedata? Industrielle aktører er blant de som nå viser interesse for bedre tilgang til helsedata. Internasjonal legemiddelindustri, utstyrsprodusenter og andre er ivrige etter å få tilgang til norske helsedata hvis eller når de blir mer tilgjengelige. Det er positivt fordi det kan fremme innovasjon og ny kunnskap, men det krever god forvaltning av interesser. Hvordan kan vi gi sterke industrielle og andre aktører tilgang til norske helsedata, samtidig som vi sikrer fortsatt demokratisk styring, personvern og individuelle rettigheter, og sørger for at både kunnskapen og de økonomiske gevinstene kommer hele befolkningen, helse- og omsorgtjenestene og norske myndigheter til gode? Kan vi lære av oljepolitikken der fremsynte strateger i politikk og forvaltning sørget for at Norge ikke solgte oljen, men sikret styring og fremtidige verdier for hele landet? Jeg håper det, og jeg tror det. Men det krever politisk erkjennelse av denne utfordringen. Og det haster.

Familiebildet med Medisinsk fødselsregister viser en vital femtiåring med betydelige muligheter foran seg. Opplysninger om svangerskap og fødsel vil alltid være vesentlige for å få kunnskap for bedre helse og mindre ulikhet i Norge og globalt. Spørsmålet er hvordan vi kan gjøre det enda bedre i fremtiden.

Gratulerer med femti fruktbare år! 